\title{
Exploring Common Bean Fresh Pod Market in East African Region: A Case of Uganda ${ }^{\dagger}$
}

\author{
Stanley Tamusange Nkalubo 1,*, Richard Ariong ${ }^{1}$, Gabriel Luyima ${ }^{1}$, Clare Mukankusi Mugisha ${ }^{2}$ \\ and Jean Claude Lubyogo ${ }^{3}$ \\ 1 National Agricultural Research Organisation, P.O. Box 7084, Kampala, Uganda; \\ marichard98@gmail.com (R.A.); gbluyima@gmail.com (G.L.) \\ 2 Alliance of Bioversity International and International Center for Tropical Agriculture (CIAT)-Pan Africa \\ Bean Research Alliance (PABRA), P.O. Box 6247, Kampala, Uganda; c.mukankusi@cgiar.org \\ 3 Alliance of Bioversity International and International Center for Tropical Agriculture (CIAT)-Pan Africa \\ Bean Research Alliance (PABRA), P.O. Box 823-00100, Nairobi, Kenya; j.c.rubyogo@cgiar.org \\ * Correspondence: tamusange@gmail.com \\ + Presented at the third International Tropical Agriculture Conference (TROPAG 2019), Brisbane, Australia, \\ 11-13 November 2019.
}

Published: 7 April 2020

\begin{abstract}
Common bean fresh pod is a niche market product consumed worldwide including in Eastern Africa region. It is more preferred to dry bean due to the fresh taste and ease to cook. A lot of research has been done on production and disposition of dry bean product; however, little information is available on production and marketing of fresh bean pod in Uganda. The general observation indicates wide consumption of fresh bean pods however, there is limited information on its entire value chain, yet, its value cannot be undermined. Based on this background, a reconnaissance study was undertaken in Mpigi district, a major fresh bean growing area and eight retailing markets within Uganda's capital, Kampala, to understand the economic feasibility of fresh bean pod market. Using qualitative approaches, farmer and market analysis was conducted to explore and understand fresh bean market dynamics. The results show that there are over 10 varieties being sold for fresh pod, unstandardized weight measures are being used, and price variation of over $50 \%$. Additionally, unsatisfied demand for fresh pod beans is $45 \%$. The results indicate existence of a lucrative fresh pod market valued at more than USD 2.0 million within Kampala and suburbs. It was also revealed that production faces significant gaps in seed availability to ensure consistent quality supply to the market while at selling points, bronzing effect was a major challenge leading to product deterioration. Thus, interventions are needed to eliminate the existing production and marketing challenges for a sustainable fresh bean pod business.
\end{abstract}

Keywords: common dry bean; fresh bean pod; fresh bean market; bronzing; value chain; niche market

Conflicts of Interest: The author declares no conflict of interest.

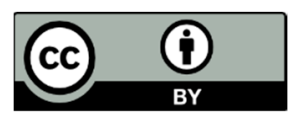

(C) 2020 by the authors. Licensee MDPI, Basel, Switzerland. This article is an open access article distributed under the terms and conditions of the Creative Commons Attribution (CC BY) license (http://creativecommons.org/licenses/by/4.0/). 